\title{
BCAP31-related syndrome: The first de novo report
}

\author{
Berardo Rinaldi $^{\mathrm{a}, *}$, Evelien Van Hoof ${ }^{\mathrm{b}}$, Anniek Corveleyn $^{\mathrm{b}}$, Annick Van Cauter ${ }^{\mathrm{c}}$, Thomy de Ravel ${ }^{\mathrm{d}}$

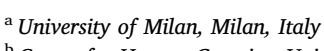 \\ ${ }^{\mathrm{b}}$ Center for Human Genetics, University Hospitals Leuven, Catholic University Leuven, Leuven, Belgium \\ ${ }^{\mathrm{c}}$ Department of Pediatrics, AZ Sint-Lucas, Brugge, Belgium \\ ${ }^{\mathrm{d}}$ Centre for Medical Genetics, Reproduction and Genetics, University Hospital Brussels, Brussels, Belgium
}

\section{A R T I C L E I N F O}

\section{Keywords:}

BCAP31

$\mathrm{Xq} 28$

DDCH syndrome

Dystonia

Central hypomyelination

Hearing loss

\begin{abstract}
A B S T R A C T
Pathogenic variants in the BCAP31 gene have recently been associated with a severe congenital neurological phenotype, named DDCH after its key features: deafness, dystonia and central hypomyelination. BCAP31 is located at the Xq28 chromosomal region and only male individuals are currently known to be affected, the pathogenic variant being usually transmitted by healthy mothers.

Here, we describe a three-year-old male child referred for severe developmental delay, failure to thrive, hearing loss and dyskinetic movements. After a conventional diagnostic workflow, including a normal array$\mathrm{CGH}$, a tentative diagnosis of dyskinetic cerebral palsy was retained. Clinical exome sequencing in the trio identified a small intragenic deletion in exon 8 of BCAP31, c.709_721del (p.Val237Trpfs*69), originated de novo and not previously reported. Based on the ACMG variant classification, this variant is predicted to be 'likely pathogenic'. Given the consistent phenotypical overlap with the subjects already ascertained with DDCH, we considered this variant to be clinically relevant for this child and causative of his condition.
\end{abstract}

\section{Introduction}

The BCAP31 gene is located in the chromosomal region $\mathrm{Xq} 28$ and encodes BAP31, a chaperone protein localized within the endoplasmic reticulum (ER) membrane and responsible for protein transportation, folding quality control and caspase8-dependant apoptosis (Grimm, 2012; Zhang and Williams, 2006). Due to its key role in ER functioning $B C A P 31$ is expressed in many tissues, including the central nervous system (Manley and Lennon, 2001).

Loss-of-function variants or small intragenic deletions of BCAP31 have been identified in seven male individuals from three unrelated families presenting with severe developmental delay, deafness, mild liver dysfunction, dystonia, central hypomyelination and poor prognosis. This phenotype was recapitulated with the acronyms DDCH syndrome (MIM \#300475) (Cacciagli et al., 2013). Another male subject with a pathogenic variant in BCAP31 and consistent phenotype has been recently described, expanding the clinical spectrum to the involvement of basal ganglia and choreoathetosis (Albanyan et al., 2017).

Besides intragenic anomalies, BCAP31 may be dysregulated by copy number variants as well. BCAP31 lies between two other OMIM genes, i.e. SLC6A8 at its $5^{\prime}$ end and $A B C D 1$ at its $3^{\prime}$ end, whose disruption is responsible for cerebral creatine deficiency (MIM \#300352) and adrenoleukodystrophy (MIM \#300100), respectively. For both these conditions, different authors have reported subjects with a more severe phenotype than usually expected. In all these cases the underlying genetic defect was a microdeletion including at least partially $B C A P 31$, in addition to either SLC6A8 or ABCD1 (Anselm et al., 2006; Corzo et al., 2002; Iwasa et al., 2013; Osaka et al., 2012); further publications have dissected the genotype-phenotype correlation of this region according to the deletion size (Calhoun and Raymond, 2014; van de Kamp et al., 2015).

This scenario depicts BCAP31 as a dosage-sensitive gene and associates its impairment to a severe neurological phenotype in males. All the BCAP31 pathogenic variants already ascertained were transmitted by healthy mothers; only in one case the mother had sensorineural hearing loss, possibly due to her carrier status for BCAP31 (Albanyan et al., 2017). Here, we present a further individual carrying the first $d e$ novo causative variant known for BCAP31.

\section{Clinical report}

This male child was born to healthy non-consanguineous parents of Belgian origin with unremarkable family history. During pregnancy ultrasound scans revealed only a slight decrease of growth parameters in the third trimester, when delivery occurred at $32+4$ weeks of gestation with an urgent $\mathrm{C}$-section due to maternal pre-eclampsia and

\footnotetext{
* Corresponding author.

E-mail address: berardo.rinaldi@unimi.it (B. Rinaldi).
} 
placental abruption. Birth parameters were: weight $1640 \mathrm{gr}$, length $42 \mathrm{~cm}$ and head circumference $28.8 \mathrm{~cm}$; Apgar scores were $7 / \mathrm{I}-8 / \mathrm{V}-$ $8 / \mathrm{X}$. Due to respiratory distress, invasive ventilation was undertaken for the first $28 \mathrm{~h}$ then followed by nasal CPAP for 8 days. He also needed surfactant replacement therapy and phototherapy for jaundice. His motor pattern appeared to be chaotic and associated with episodic myoclonus of the face and of the limbs. Neonatal neurosonography and EEG were normal whereas the auditory screening and the brainstem evoked response audiometry were both altered, arguing for bilateral sensorineural hearing loss.

At the age of two months a magnetic resonance (MRI) of the brain showed unspecific T2-weighted hyperintense signal of the periventricular white matter (PVWM), whose interpretation was limited due to his young age; notably, there was no signal alteration of basal ganglia. From the first months failure to thrive coexisted with a significant gastroesophageal reflux (GER). By the age of four months, the eye contact was still poor and neurological examination highlighted gazeevoked nystagmus, opisthotonus, athetoid wandering movements, axial hypotonia, hypertonia of lower limbs with a positive plantar reflex. At eleven months he underwent positioning of cochlear implant, without clear improvement. At fifteen months his motor functioning level showed an equivalent age of about two months (Peabody Developmental Motor Scale, PDMS-2). Additional normal investigations included a CT scan of petrous temporal bones, ophthalmoscopy, abdominal ultrasound, plasma serology for TORCH complex, plasma amino acids, urinary organic acids and array-CGH (average resolution $\sim 200 \mathrm{~kb}$ ). Based on clinical presentation and investigations, the diagnosis of dyskinetic cerebral palsy was retained.

His evolution has been characterized by poor psychomotor development with persistence of dyskinetic movements, unsatisfactory growth, difficult feeding and severe GER requiring percutaneous endoscopic gastrostomy (PEG) and Nissen fundoplication respectively, multiple hospitalizations due to recurrent infections (on average one episode every two months). In at least three cases of infection a slight transient increase in transaminases was noticed (AST $70 \mathrm{mU} / \mathrm{mL}$, ALT $109 \mathrm{mU} / \mathrm{mL}$ ). At 18 months he experienced febrile seizures, then followed by a partial seizure with myoclonus of the right leg and a generalized seizure at the age of 34 months. EEG never revealed epileptic foci but anti-epileptic drugs were prescribed due to his general condition.

His last clinical evaluation was at the age of 28 months. His height was $-2.9 \mathrm{SD}$, his weight $-2.4 \mathrm{SD}$ and his head circumference $-1.6 \mathrm{SD}$ (it was less than -2 SD till 18 months). He was wheelchair-bound with incomplete control of the head and inconstant eye contact. His motor activity was characterized by intentional and dystonic movements; gaze-evoked nystagmus and bruxism were also noticed. Additional features were: positional brachycephaly, poliosis, bitemporal narrowing, straight eyebrows, deep-set eyes, bluish sclerae, inconstant esotropia, short philtrum, micrognathia. Parents reported hands and feet to be often cold. His therapy includes proton-pump inhibitors, aerosol for bronchial hyperactivity (of family origin), antibiotic prophylaxis and clonazepam. He attends kinesiotherapy and swallowing logopedy.

\section{Methods and results}

DNA extraction and array-CGH were carried out according to routine protocols (Winters et al., 2017). To assess single nucleotide variants we performed targeted resequencing of OMIM genes in the familial trio. Library preparation for all samples was performed using TruSeq DNA Sample Preparation Kit (Illumina, CA, USA). All exons of the target genes were enriched through hybridization with an in-house developed in-solution Nimblegen SeqCap EZ capture (Roche Nimblegen, WI, USA) and the target-enriched libraries were amplified and sequenced on the Hiseq 2500 (Illumina, CA, USA) by paired-end sequencing. An in-house developed pipeline was used for further bioinformatics processing of the sequencing data (base-calling, alignment and variant calling were performed with the GATK package). Variant annotation and classification were executed within the Cartagenia BENCHlab NGS module (Cartagenia v4.1, Agilent, CA, USA) according to ACMG guidelines for interpretation of sequence variants. With this approach we identified a total of 66 de novo variants, of which 65 showed high frequencies in the general population database or were deep intronic ( $>20$ bp far from intron-exon boundaries). The only variant predicted to be deleterious and consistent with the phenotype was the hemizygous variant (NC_000023.10:g.152966411ATGGGACC ATCTAC > A; NM_001139441.1:c.709_721del; p. Val237Trpfs*69) in the BCAP31 gene. This variant is absent in any population or disease database (GnomAD, HGMD, Clinvar) and was confirmed with Sanger sequencing. The hemizygous deletion of 13 base pairs occurs in the last exon of BCAP31, positioned 17 base pairs before the stop codon. Its presence disrupts the reading frame, causing readthrough across the position of the normal stop codon. This is predicted to result in a 304 amino acid long protein, the wild type protein being of 246 amino acids. We classified this variant as likely pathogenic (class 4), based on its de novo status (ACMG criteria PS2), the absence in control population databases (ACMG criteria PM2), its status of protein length changing variant in haploinsufficiency sensitive gene (ACMG criteria PM4) and the specific overlap with previously reported phenotype (ACMG criteria PP4).

\section{Discussion}

We describe a 3-year male individual referred with a tentative diagnosis of dyskinetic cerebral palsy. Target resequencing of OMIM genes on the familial trio identified a hemizygous likely pathogenic variant in the BCAP31 gene not previously reported. Pathogenic variants of this X-linked gene have been recently associated to a severe neurologic condition featuring deafness, dystonic movements and central hypomyelination (Cacciagli et al., 2013). Though all the mutations reported so far were inherited, in our case the segregation analysis revealed the variant to be de novo.

Our variant affects the C-terminus of the protein, possibly resulting in a transcript longer than the canonical wild-type one. Interestingly, one of the individuals reported by Cacciagli et al. carried a sub-terminal deletion of BCAP31, suggesting that C-terminus disruption might be relevant for the disease. Among the three core signs firstly characterized by Cacciagli et al. our index subject certainly shares the first two, whereas regarding his possible degree of central hypomyelination the cerebral MRI performed at two months of age revealed unspecific T2weighted hyperintense PVWM, suggestive for delayed myelination (Table 1). The interpretation of this finding must take into account the age-related dependence of the myelination process (Guleria and Kelly, 2014) and the sensitivity of the periventricular region to injuries in preterm infants (Benders et al., 2014). On the other hand, periventricular hypomyelination was also highlighted in two unrelated individuals among those described by Cacciagli et al. aged 5.6 and 11 years at the time of cerebral MRI (for the latter along with both cerebral cortical and cerebellar atrophy). Therefore, though it is not possible to exclude the effect of some confounding factors, MRI findings described in our case are consistent with what already known for DDCH.

Beyond the three main signs, our index subject shares other phenotypical traits with DDCH (Table 1). His facial appearance presents only minor dysmorphic features and strongly recalls the subject described by Albanyan et al. Severe failure to thrive led auxological parameters to maintain constantly below $-2 \mathrm{SD}$, even when age-matched for prematurity; height growth has been more regular than weight gain, the latter remarkably improving after PEG. His psychomotor development is severely delayed and he is wheelchair-bound, speech is absent and communicative skills are limited to eye contact. Both epilepsy and mild liver dysfunction showed a reduced penetrance in 
Table 1

Clinical comparison of individuals with BCAP31-associated syndrome.

\begin{tabular}{|c|c|c|c|c|c|c|c|c|c|}
\hline & \multicolumn{7}{|c|}{ Cacciagli et al. (2013) } & \multirow{3}{*}{$\begin{array}{l}\begin{array}{l}\text { Albanyan et al. } \\
(2017)\end{array} \\
\text { Singleton }\end{array}$} & \multirow{3}{*}{$\begin{array}{l}\text { This report } \\
\text { Singleton }\end{array}$} \\
\hline & \multicolumn{2}{|l|}{ Family 1} & \multicolumn{4}{|l|}{ Family 2} & \multirow{2}{*}{$\begin{array}{l}\text { Family } 3 \\
\text { III.1 }\end{array}$} & & \\
\hline & III.2 & III.3 & III.5 & III.6 & III.7 & IV.1 & & & \\
\hline Variant & \multicolumn{2}{|c|}{$\begin{array}{l}\text { c. } 194-2 A>G \\
\text { p.Ile64fs*25 }\end{array}$} & \multicolumn{4}{|c|}{ Exon 8 deletion } & $\begin{array}{l}\text { c. } 97 \mathrm{C}>\mathrm{T} \\
\text { p.Gln } 33^{*}\end{array}$ & $\begin{array}{l}\text { c.533_536dup } \\
\text { p.Ser180Alafs*6 }\end{array}$ & $\begin{array}{l}\text { c.709_721del } \\
\text { p.Val237Trps*69 }\end{array}$ \\
\hline Inheritance & \multicolumn{2}{|c|}{ healthy mother } & \multicolumn{3}{|c|}{ healthy mother } & $\begin{array}{l}\text { healthy } \\
\text { mother }\end{array}$ & healthy mother & $\begin{array}{l}\text { mother with } \\
\text { bilateral hearing } \\
\text { loss }\end{array}$ & de novo \\
\hline Gender & male & male & male & male & male & male & male & male & male \\
\hline Age of onset & congenital & congenital & congenital & $6 \mathrm{w}$ & $6 \mathrm{w}$ & congenital & congenital & first weeks & congenital \\
\hline Age of death & $24 \mathrm{y}$ & $13 y$ & $7 \mathrm{~m}$ & $1 \mathrm{y}$ & $2 y$ & living & $3 y$ & living & living \\
\hline \multicolumn{10}{|c|}{ MAIN SIGNS AND SYMPTOMS } \\
\hline Deafness & + & + & NA & + & + & + & $+/-$ & + & + \\
\hline Dystonia & ++ & ++ & NA & +++ & +++ & ++ & +++ & ++ & ++ \\
\hline $\begin{array}{l}\text { White matter } \\
\text { (performed at) }\end{array}$ & NP & $\begin{array}{l}\text { PVWM } \\
(11 \mathrm{y})\end{array}$ & NP & NP & NP & $\begin{array}{l}\text { PVWM } \\
(5.6 \mathrm{y})\end{array}$ & $\begin{array}{l}\text { diffuse } \\
\text { hypomyelination } \\
(2.5 \mathrm{y})\end{array}$ & NA & $\begin{array}{l}\text { PVWM } \\
(2 \mathrm{~m})\end{array}$ \\
\hline $\begin{array}{l}\text { Additional MRI } \\
\text { findings }\end{array}$ & & $\begin{array}{l}\text { atrophy of } \\
\text { cerebral } \\
\text { cortex and } \\
\text { cerebellum }\end{array}$ & & & & & $\begin{array}{l}\text { atrophy of CC, } \\
\text { frontal lobe, } \\
\text { white matter }\end{array}$ & $\begin{array}{l}\text { bilateral } \\
\text { globus pallidus } \\
\text { hyperintensity }\end{array}$ & \\
\hline Liver function tests & \multicolumn{7}{|c|}{ transitory episodes of a 2 - to 3 -fold increase in 4 out of 7 subjects } & $\begin{array}{l}+/++ \text { elevation } \\
\text { of AST and ALT } \\
\text { during illnesses }\end{array}$ & $\begin{array}{l}+/++ \text { elevation } \\
\text { of AST and ALT } \\
\text { during illnesses }\end{array}$ \\
\hline $\begin{array}{l}\text { Facial } \\
\quad \text { dysmorphisms }\end{array}$ & ++ & + & NA & + & + & + & $+/-$ & + & + \\
\hline Failure tothrive & $\begin{array}{l}+++ \\
\text { (IUGR, W }-7 \\
\text { SDs, } \mathrm{H}-8 \\
\text { SDs) }\end{array}$ & $\begin{array}{l}+++ \\
\text { (IUGR, W }-6 \\
\text { SDs, } \mathrm{H}-5 \\
\text { SDs) }\end{array}$ & NA & + & + & +++ & $\begin{array}{l}+ \\
\text { (IUGR, 0-3 y: W/H } \\
-3 \text { SDs, > } 3 \text { y: } \\
\text { W/H }-2 \text { SDs) }\end{array}$ & $\begin{array}{l}4.5 \mathrm{y}: \mathrm{H}<-2 \mathrm{SDs} \text {, } \\
\mathrm{W} \text { normal range } \\
\text { (gastrostomy) }\end{array}$ & $\begin{array}{l}28 \mathrm{~m}: \mathrm{H}-2.9 \mathrm{SDs} \\
\mathrm{W}-2.4 \mathrm{SDs} \\
\text { (gastrostomy) }\end{array}$ \\
\hline Microcephaly & $\begin{array}{l}+++ \\
(-5 \text { SDs })\end{array}$ & $\begin{array}{l}+++ \\
(-5 \text { SDs })\end{array}$ & NA & NA & NA & $\begin{array}{l}+ \\
(2 \mathrm{~m}:-3 \\
\text { SDs, } 2 \mathrm{y}:-2 \\
\text { SDs) }\end{array}$ & $\begin{array}{l}++ \\
(0-6 \mathrm{~m}:-2 \mathrm{SDs} \\
>6 \mathrm{~m}:-3 \mathrm{SDs})\end{array}$ & $\begin{array}{l}+ \\
(<-2 \text { SDs })\end{array}$ & $\begin{array}{l}+/- \\
(0-18 \mathrm{~m}:<-2 \text { SDs } \\
>18 \mathrm{~m}:-1.6 \mathrm{SDs})\end{array}$ \\
\hline $\begin{array}{l}\text { Motor } \\
\qquad \text { (acquired at) }\end{array}$ & none & none & none & none & $\begin{array}{l}\text { head } \\
(1 \mathrm{y})\end{array}$ & $\begin{array}{l}\text { head } \\
(6 \mathrm{~m}) \text {, } \\
\text { sitting } \\
(5 \mathrm{y}) \text {, } \\
\text { wheelchair } \\
(8 \mathrm{y})\end{array}$ & $\begin{array}{l}\text { head } \\
(1 \mathrm{y}, \text { lost at } 1.5 \mathrm{y})\end{array}$ & none & none \\
\hline Neurologic & $\begin{array}{l}\text { pyramidal } \\
\text { signs, } \\
\text { quadriplegia }\end{array}$ & $\begin{array}{l}\text { pyramidal } \\
\text { signs, } \\
\text { quadriplegia }\end{array}$ & NA & $\begin{array}{l}\text { pyramidal } \\
\text { signs, } \\
\text { quadriplegia }\end{array}$ & $\begin{array}{l}\text { pyramidal } \\
\text { signs, } \\
\text { quadriplegia }\end{array}$ & $\begin{array}{l}\text { pyramidal } \\
\text { signs, } \\
\text { paraplegia }\end{array}$ & $\begin{array}{l}\text { pyramidal signs, } \\
\text { quadriplegia }\end{array}$ & $\begin{array}{l}\text { choreoathetosis, } \\
\text { pyramidal signs, } \\
\text { quadriplegia }\end{array}$ & $\begin{array}{l}\text { pyramidal signs, } \\
\text { quadriplegia }\end{array}$ \\
\hline $\begin{array}{l}\text { Seizure } \\
\quad \text { (onset) }\end{array}$ & $\begin{array}{l}+ \\
(4 \mathrm{y})\end{array}$ & + & NA & none & none & $\begin{array}{l}+ \\
(8 \mathrm{y})\end{array}$ & none & none & $\begin{array}{l}+ \\
(3 \mathrm{y})\end{array}$ \\
\hline Ocular & $\begin{array}{l}\text { Congenital } \\
\text { strabismus }\end{array}$ & $\begin{array}{l}\text { Congenital } \\
\text { strabismus, } \\
\text { abnormal eye } \\
\text { movements }\end{array}$ & NA & $\begin{array}{l}\text { optic } \\
\text { atrophy }\end{array}$ & $\begin{array}{l}\text { congenital } \\
\text { strabismus }\end{array}$ & $\begin{array}{l}\text { congenital } \\
\text { strabismus, } \\
\text { optic } \\
\text { atrophy }\end{array}$ & $\begin{array}{l}\text { congenital } \\
\text { strabismus }\end{array}$ & NA & $\begin{array}{l}\text { nystagmus, } \\
\text { bluish sclerae, } \\
\text { inconstant } \\
\text { esotropia }\end{array}$ \\
\hline
\end{tabular}

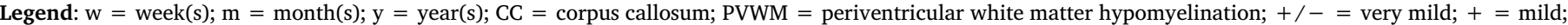

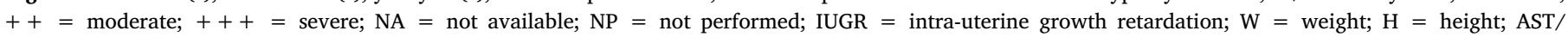
ALT $=$ hepatic transaminase.

subjects with BCAP31 haploinsufficiency (Cacciagli et al., 2013). In our case, the child had three isolated episodes of seizure (one of likely febrile origin) not followed by persistent EEG anomalies and his hepatic involvement was restricted to low and transient transaminases increases during febrile episodes. Bruxism and nystagmus were not previously described and might be due to the involvement of basal ganglia, as suggested by the MRI findings from Albanyan et al. and from the association of these two signs with movement disorders (Ella et al., 2017; Jung and Kim, 2019).

BAP31 protein participates on several processes, such as protein fate regulation, ER-Golgi crosstalk and apoptosis. To assess the consequences of BAP31 impairment, Cacciagli et al. investigated its functioning in fibroblasts from affected individuals and identified abnormal ER morphology and disorganization of the Golgi apparatus. The authors suggested that the perturbation of the ER-Golgi interaction might lead to myelination defect, as already observed for other hypomyelinating disorders (Numata et al., 2013). Some insights about the hepatic involvement have been provided by comparing the phenotype of individuals with Xq28 deletion of different sizes. In fact, only combined deletions of BCAP31 and $A B C D 1$ would be responsible for severe hepatic cholestasis, supporting the former playing a role in hepatic homeostasis, possibly through bile metabolism (van de Kamp et al., 2015). However, the molecular mechanisms by which BCAP31 haploinsufficiency would then result in DDCH remain to be fully elucidated.

In conclusion, we report the ninth unrelated individual presenting with the DDCH phenotype and describe the first pathogenic de novo variant in BCAP31. Despite the co-occurrence of deafness, dystonia and central hypomyelination is not uncommon in patients with severe congenital neurological conditions, such a clinical presentation may be 
enough specific to recall the involvement of BCAP31.

\section{Acknowledgments}

The authors thank the family for participating in this study.

\section{References}

Albanyan, S., Al Teneiji, A., Monfared, N., Mercimek-Mahmutoglu, S., 2017. BCAP31associated encephalopathy and complex movement disorder mimicking mitochondrial encephalopathy. Am. J. Med. Genet. 173, 1640-1643. https://doi.org/10.1002/ ajmg.a.38127.

Anselm, I.M., Alkuraya, F.S., Salomons, G.S., Jakobs, C., Fulton, A.B., Mazumdar, M., Rivkin, M., Frye, R., Poussaint, T.Y., Marsden, D., 2006. X-linked creatine transporter defect: a report on two unrelated boys with a severe clinical phenotype. J. Inherit. Metab. Dis. 29, 214-219. https://doi.org/10.1007/s10545-006-0123-4.

Benders, M.J.N.L., Kersbergen, K.J., de Vries, L.S., 2014. Neuroimaging of white matte injury, intraventricular and cerebellar hemorrhage. Clin. Perinatol. 41, 69-82. https://doi.org/10.1016/j.clp.2013.09.005.

Cacciagli, P., Sutera-Sardo, J., Borges-Correia, A., Roux, J.C., Dorboz, I., Desvignes, J.P., Badens, C., Delepine, M., Lathrop, M., Cau, P., Lévy, N., Girard, N., Sarda, P., Boespflug-Tanguy, O., Villard, L., 2013. Mutations in BCAP31 cause a severe XLinked phenotype with deafness, dystonia, and central hypomyelination and disorganize the Golgi apparatus. Am. J. Hum. Genet. 93, 579-586. https://doi.org/10. 1016/j.ajhg.2013.07.023.

Calhoun, A.R.U.L., Raymond, G.V., 2014. Distal Xq28 microdeletions: clarification of the spectrum of contiguous gene deletions involving ABCD1, BCAP31, and SLC6A8 with a new case and review of the literature. Am. J. Med. Genet. 164, 2613-2617. https:// doi.org/10.1002/ajmg.a.36661.

Corzo, D., Gibson, W., Johnson, K., Mitchell, G., LePage, G., Cox, G.F., Casey, R., Zeiss, C., Tyson, H., Cutting, G.R., Raymond, G.V., Smith, K.D., Watkins, P.A., Moser, A.B., Moser, H.W., Steinberg, S.J., 2002. Contiguous deletion of the X-linked adrenoleukodystrophy gene (ABCD1) and DXS1357E: a novel neonatal phenotype similar to peroxisomal biogenesis disorders. Am. J. Hum. Genet. 70, 1520-1531. https://doi. org/10.1086/340849.

Ella, B., Ghorayeb, I., Burbaud, P., Guehl, D., 2017. Bruxism in movement disorders: a comprehensive review. J. Prosthodont. https://doi.org/10.1111/jopr.12479.

Grimm, S., 2012. The ER-mitochondria interface: the social network of cell death Biochim. Biophys. Acta 1823, 327-334. https://doi.org/10.1016/j.bbamcr.2011.11. 018.

Guleria, S., Kelly, T.G., 2014. Myelin, myelination, and corresponding magnetic resonance imaging changes. Radiol Clin N. Am. 52, 227-239. https://doi.org/10.1016/ j.rcl.2013.11.009.

Iwasa, M., Yamagata, T., Mizuguchi, M., Itoh, M., Matsumoto, A., Hironaka, M., Honda, A., Momoi, M.Y., Shimozawa, N., 2013. Contiguous ABCD1 DXS1357E deletion syndrome: report of an autopsy case. Neuropathology 33, 292-298. https://doi.org/ 10.1111/j.1440-1789.2012.01348.x.

Jung, I., Kim, J.-S., 2019. Abnormal eye movements in parkinsonism and movement disorders. J. Mov. Disord. 12, 1-13. https://doi.org/10.14802/jmd.18034.

Manley, H.A., Lennon, V.A., 2001. Endoplasmic reticulum membrane-sorting protein of lymphocytes (BAP31) is highly expressed in neurons and discrete endocrine cells. J. Histochem. Cytochem. 49, 1235-1243. https://doi.org/10.1177/ 002215540104901005.

Numata, Y., Morimura, T., Nakamura, S., Hirano, E., Kure, S., Goto, Y.I., Inoue, K., 2013. Depletion of molecular chaperones from the endoplasmic reticulum and fragmentation of the Golgi apparatus associated with pathogenesis in Pelizaeus-Merzbacher disease. J. Biol. Chem. 288, 7451-7466. https://doi.org/10.1074/jbc.M112.435388.

Osaka, H., Takagi, A., Tsuyusaki, Y., Wada, T., Iai, M., Yamashita, S., Shimbo, H., Saitsu, H., Salomons, G.S., Jakobs, C., Aida, N., Toshihiro, S., Kuhara, T., Matsumoto, N. 2012. Contiguous deletion of SLC6A8 and BAP31 in a patient with severe dystonia and sensorineural deafness. Mol. Genet. Metab. 106, 43-47. https://doi.org/10. 1016/j.ymgme.2012.02.018.

van de Kamp, J.M., Errami, A., Howidi, M., Anselm, I., Winter, S., Phalin-Roque, J., Osaka, H., van Dooren, S.J.M., Mancini, G.M., Steinberg, S.J., Salomons, G.S., 2015. Genotype-phenotype correlation of contiguous gene deletions of SLC6A8, BCAP31 and ABCD1. Clin. Genet. 87, 141-147. https://doi.org/10.1111/cge.12355.

Winters, L., Van Hoof, E., De Catte, L., Van Den Bogaert, K., de Ravel, T., De Waele, L., Corveleyn, A., Breckpot, J., 2017. Massive parallel sequencing identifies RAPSN and PDHA1 mutations causing fetal akinesia deformation sequence. Eur. J. Paediatr. Neurol. 21, 745-753. https://doi.org/10.1016/j.ejpn.2017.04.641.

Zhang, Y., Williams, D.B., 2006. Assembly of MHC class I molecules within the endoplasmic reticulum. Immunol. Res. 35, 151-162. https://doi.org/10.1385 IR:35:1:151. 